\title{
Soil Depth and Changes in Dry Mass and Competitive Intensity of Two $\mathrm{C}_{4}$ Grasses
}

\author{
J. K. Bush ${ }^{1}$, O. W. Van Auken ${ }^{2 *}$ \\ ${ }^{1}$ Environmental Science, College of Sciences, University of Texas at San Antonio, San Antonio, USA; ${ }^{2}$ Department of Biology, \\ University of Texas at San Antonio, San Antonio, USA. \\ Email: *oscar.vanauken@utsa.edu
}

Received November 21 ${ }^{\text {st }}, 2013$; revised December $22^{\text {nd }}, 2013$; accepted January $5^{\text {th }}, 2014$

Copyright (c) 2014 J. K. Bush, O. W. Van Auken. This is an open access article distributed under the Creative Commons Attribution License, which permits unrestricted use, distribution, and reproduction in any medium, provided the original work is properly cited. In accordance of the Creative Commons Attribution License all Copyrights (C) 2014 are reserved for SCIRP and the owner of the intellectual property J. K. Bush, O. W. Van Auken. All Copyright (C 2014 are guarded by law and by SCIRP as a guardian.

\section{ABSTRACT}

The presence of grassland biomes and species cannot be predicted by examining bottom up causes such as precipitation and temperature. Top down causes including herbivory and fire seem to be major controlling aspects with other factors secondary. We examined soil depth and competitive ability of two North American $\mathrm{C}_{4}$ grasses in a greenhouse experiment. Changes in dry mass were determined and competitive intensity was calculated for both species. Species were grown separately or together in pots 30,90 , or $180 \mathrm{~cm}$ deep. When grown in monoculture, Schizachyrium scoparium total and belowground dry mass increased from the 30 to $90 \mathrm{~cm}$ depth, with no further significant increase from 90 to $180 \mathrm{~cm}$. Aboveground dry mass did not increase significantly with depth. Total dry mass of Buchloe dactyloides increased significantly with depth when grown in monoculture. Aboveground dry mass increased from 30 to $90 \mathrm{~cm}$ depth but not from 90 to $180 \mathrm{~cm}$. Belowground dry mass of $B$. dactyloides did not increase significantly with depth. In $180 \mathrm{~cm}$ pots, $53 \%$ of $S$. scoparium root dry mass was in the top $30 \mathrm{~cm} ; 74 \%$ of $B$. dactyloides root dry mass was in the top $30 \mathrm{~cm}$. Roots of B. dactyloides were not found deeper than $90 \mathrm{~cm}$. Aboveground dry mass of $S$. scoparium was not different in mixture or monoculture at any depth. Buchloe dactyloides aboveground dry mass in mixture was significantly lower than monoculture at the 30 cm depth, but not at 90 or $180 \mathrm{~cm}$. The greatest competitive intensity was in the shallow soil pots. Soil depth could partially explain mosaics found in $\mathrm{C}_{4}$ grasslands where both species were found together with $S$. scoparium on deeper soils and $B$. dactyloides on shallower soils.

\section{KEYWORDS}

\section{$\mathrm{C}_{4}$ Grasses; Buffalo Grass; Little Bluestem; Dry Mass; Depth; Competitive Intensity; Semi-Arid Grasslands}

\section{Introduction}

Native prairies in North America once covered almost four million $\mathrm{km}^{2}$, but today only about one percent remains, with most converted to domestic use [1]. With changes, considerable encroachment and invasion of woody and herbaceous species have occurred [2]. On a large scale, grassland communities' seem relatively uniform, but on a small scale, they resemble a mosaic of miniature successions or patches and species composition may be controlled by different factors including resources $[3,4]$. These successions start with large or small scale distur-

\footnotetext{
"Corresponding author.
}

bances creating patches or openings caused by fire, burrowing animals, large or small grazers, and drought [3]. These gaps or patches may serve as a reset mechanism [5] to reopen mature grasslands to early successional species [3] and then proceed in time toward a mature community. These patches may contain few or many species in various combinations and should be viewed both temporally and spatially [6].

Early successional species seem to require reduced competition or lower competitive intensity [7-9], increased soil surface light levels and soil resources for establishment [10-12]. These characteristics are found in disturbances, clearings, openings, or gaps. Many annuals 
are opportunistic, early successional species that could colonize grassland gaps and the characteristics of the gaps would determine the colonizing species [3]. As time passes, other species, with different characteristics and requirements, would establish in these gaps or patches. With the change in species composition, from early to mid or late, the community characteristics would also change. Late successional communities would not have the highly repetitive disturbance characteristics of early communities [9,13,14].

Grassland species and resources have patchy or heterogeneous distributions. In arid and semi-arid communities, water and soil nutrients are factors limiting the establishment and growth of many of these species [15-17]. In addition, soil depth and composition can directly determine water and nutrient availability and thus root depth and distribution [18]. In grasslands, $83 \%$ of the total belowground biomass is located in the upper $30 \mathrm{~cm}$ of soil [19]. However, differential rooting depth may allow partitioning of belowground resources leading to changes in growth and a reduction in belowground competition [20-23]. This partitioning may lead to spatial and temporal niche differentiation promoting coexistence of various species in grasslands [22-24].

In this paper, we examine the role of soil depth and how it influences aboveground, belowground and total dry mass of $S$. scoparium and B. dactyloides. In addition, we estimate how competitive intensity changes as a function of soil depth when the two species are grown together. We used three soil depths-30, 90, and $180 \mathrm{~cm}$. We hypothesized that when grown in monoculture, above-, belowground and total dry mass of both species would increase from 30 to $90 \mathrm{~cm}$ depth, and that dry mass at $180 \mathrm{~cm}$ would be the same as at the $90 \mathrm{~cm}$ soil depth due to few roots in the deepest soil. We hypothesize that competitive intensity would be greatest in the shallowest soil depth examined $(30 \mathrm{~cm})$, but at the greater depths (90 and $180 \mathrm{~cm}$ ) competitive intensity would decrease due to increasing soil resources and/or resource partitioning between the species.

\section{Species Ecology, Characteristics and Distribution}

Schizachyrium scoparium (Michx.) Nash. little bluestem, a mid-grass and Buchloe dactyloides (Nutt.) Engelm. buffalo grass, a shortgrass, can coexist in various grasslands [25-27]. Schizachyrium scoparium seems to increase on wetter-deeper soils and $B$. dactyloides increases on drier-shallower soils [28]. Schizachyrium scoparium and $B$. dactyloides can coexist on shallow-low nutrient soils in arid and semi-arid grasslands; but B. dactyloides would dominate on shallow-high nutrient soils [12]. However, effects of soil depth on competitive ability and distribution of these two species is not known.
Thus, soil heterogeneity may play a role in determining the distribution and abundance of these two species.

The heterogeneity could be due to soil fertility, soil depth, or both; and could determine how the species compete and how they are distributed [12]. The ecological niche of these two species could be related to their rooting structure (shallow versus deep roots) or drought tolerance, and one species would usually be found on shallow-dry soils and the other on deep-wet soils. Thus, competition between the species could be reduced because of niche separation, which could explain their coexistence [29].

Schizachyrium scoparium occurs across North America, from Canada south to Mexico [30]. It has been found in all of the states in the continental United States, except Nevada and Alaska. Schizachyrium scoparium is an erect ( 0.5 to $2 \mathrm{~m}$ tall), $\mathrm{C}_{4}$, native, warm-season, perennial grass that exhibits both a caespitose and sod-forming habit [31-33]. The mature root system is a network of finely branched rootlets to the third order [34]. The largest roots have a diameter of 0.5 to $1 \mathrm{~mm}$, but root length shows considerable plasticity with length varying by soil type. Longer roots occur in sandy soils more than in silt loams, and may reach a length of $2.45 \mathrm{~m}$. An example of the root distribution from a soil monolith taken from within a S. scoparium monoculture showed that $85.8 \%$ of the root biomass occurred in the top $15 \mathrm{~cm}$ soil depth, 5.3\% in the next $15 \mathrm{~cm}$, and $2.3 \%, 1.4 \%$, and $2 \%$ in the next three 30 cm soil depths [34]. A comparison of S. scoparium root dry mass and distribution with depth in pastures under different grazing frequency showed that the depth distribution was the same across pastures, but there was a decrease in the dry mass with depth as grazing pressure increased [35].

Buchloe dactyloides occurs from Minnesota west to central Montana, and south to eastern Louisiana, Texas, New Mexico, eastern Arizona, and northern Mexico [36]. It is a $\mathrm{C}_{4}$, warm-season, native, perennial, shortgrass which grows up to $30 \mathrm{~cm}$ in height [33]. Buchloe dactyloides is drought-, heat-, and cold-resistant. The roots of B. dactyloides are finer than those of most North American prairie grasses with a diameter $<1 \mathrm{~mm}$. They tend to spread horizontally 15 to $46 \mathrm{~cm}$ in the top $15 \mathrm{~cm}$ of soil and to a depth of $180 \mathrm{~cm}$ [34]. The root dry mass taken from a soil monolith in a $B$. dactyloides monoculture showed the top $15 \mathrm{~cm}$ of soil contained $70 \%$ of the total dry mass, with $11.5 \%$ occurring in the next $15 \mathrm{~cm}$, and 11,4 , and $3 \%$ of the dry mass in the next three $30 \mathrm{~cm}$ soil depth sequences [34,37].

\section{Materials and Methods}

Schizachyrium scoparium and Buchloe dactyloides seeds were obtained from a commercial seed company. A native Patrick soil which supports the growth of both spe- 
cies was used in these experiments. Soil was the upper 20 $\mathrm{cm}$ of a clayey-over-sandy, carbonatic-thermic, typic calciustoll, with the "A" horizon depth from 25 to $41 \mathrm{~cm}$ [38] and was collected near the University of Texas at San Antonio ( $29^{\circ} 34^{\prime} 55.55 N$, $\left.98^{\circ} 37^{\prime} 49.18 W\right)$. Soil analysis indicated $7.5 \mathrm{~g} \cdot \mathrm{kg}^{-1}$ carbon, $11.6 \mathrm{~g} \cdot \mathrm{kg}^{-1}$ calcium, 1.3 $\mathrm{g} \cdot \mathrm{kg}^{-1}$ magnesium, $1.0 \mathrm{mg} \cdot \mathrm{kg}^{-1}$ total nitrogen, 12.0 $\mathrm{mg} \cdot \mathrm{kg}^{-1}$ phosphorus, $138.0 \mathrm{mg} \cdot \mathrm{kg}^{-1}$ potassium, and 196.0 $\mathrm{mg} \cdot \mathrm{kg}^{-1}$ sulfur. Plants were grown in a fiberglass greenhouse where daytime temperatures ranged from $26^{\circ} \mathrm{C}$ to $38^{\circ} \mathrm{C}$. Photosynthetically active photon flux density (PPFD, 400 to $700 \mathrm{~nm}$ ) in the greenhouse was $760 \pm 96$ $\mu \mathrm{mol} \cdot \mathrm{m}^{-2} \cdot \mathrm{s}^{-1}$ (mean \pm 1 standard deviation), while outside mean PPFD was $2090 \pm 139 \mu \mathrm{mol} \cdot \mathrm{m}^{-2} \cdot \mathrm{s}^{-1}$, with the sun at its zenith on a clear summer day. Light intensity was measured with a LI-Cor LI-88 integrating quantum sensor. Plants were watered as needed with deionized water, usually every day to maintain field capacity.

To examine effects of soil depth on above-, belowground and total dry mass of $S$. scoparium and $B$. dactyloides plants were grown in pots with three depths or lengths (30, 90, or $180 \mathrm{~cm}$ ). There were five replications of each species and pot depth or length. To examine the effects of soil depth on aboveground dry mass and competitive intensity of the two species, a replacement experiment [39] was used. There were three main effects: species (2 levels; S. scoparium or B. dactyloides), soil depth (3 levels; 30, 90, or $180 \mathrm{~cm}$ ), and planting combination (2 levels; alone [monoculture] or together [mixture]). There were five replications of each treatment, and density was held constant at two plants per pot. Thus, the proportion of Schizachyrium: Buchloe were 2:0, 1:1, and 0:2 plants per pot.

Seeds of both species were planted in the greenhouse on March 24 in 10-cm-diameter plastic pots (PVC pipe), with the bottom sealed with plastic bags (to prevent leaching of nutrients and water). Pots were 30,90 , and $180-\mathrm{cm}$-long and contained 2.4, 8.0, and $18.0 \mathrm{~kg}$ of air dried and sieved Patrick soil (described above), respectively. This resulted in the following nutrient amounts for the 30, 90 and $180 \mathrm{~cm}$ pots: $\mathrm{N}\left(2.4,8.0,18.0 \mathrm{mg} \cdot \operatorname{pot}^{-1}\right)$, $\mathrm{P}$ (28.8, 96.0, and $\left.216.0 \mathrm{mg} \cdot \mathrm{pot}^{-1}\right)$, and K (331.2, 1,104.0, and $2484.0 \mathrm{mg} \cdot \mathrm{pot}^{-1}$ ). No additional nutrients were added, and watering occurred $a d$ lib to insure that water was not limiting and soil remained at field capacity. After 18 months and two growing seasons, plant tops were harvested by clipping at the soil surface. Tops were separated by species and dried at $110^{\circ} \mathrm{C}$ to a constant mass. Ash-free belowground dry mass [40] of each monoculture pot was measured by carefully washing the soil from all the roots in each $30-\mathrm{cm}$ segment, drying to a constant mass at $110^{\circ} \mathrm{C}$, weighing, ashing at $650^{\circ} \mathrm{C}$ for $3-\mathrm{hr}$, reweighing, and subtracting. Roots of both species were fibrous and were not separated in pots containing mix- tures, and not harvested. Thus, the effect of interspecific competition was only evaluated for aboveground dry mass.

Relative competitive intensity (RCI) [29] was calculated for each species in each depth treatment as follows:

$\mathrm{RCI}=(\mathrm{Ymono}-\mathrm{Ymix}) / \mathrm{Ymono}$

where: $Y$ mono = dry mass of species in monoculture

Ymix = dry mass of species in mixture.

This measure of competitive intensity was equivalent to other common indices of competitive intensity (data not shown), [41].

To evaluate dry mass as a function of depth, only the data from monocultures were used. Above-, belowground, or total dry mass of the two species at the varying depths were appraised using two-way analyses of variance with species (2 levels) and soil depth (3 levels) as main effects, as well as the interaction term. The interaction term was not significant and removed from the model. To better understand how each species responded to depth, one-way analyses of variance of above-, belowground, or total dry mass of $S$. scoparium or B. dactyloides was used with depth (3 levels) as the main effect, followed by the Tukey-Kramer HSD multiple comparison test [42].

To compare the two species at each depth, one-way analyses of variance of above-, belowground, or total dry mass of $S$. scoparium or B. dactyloides at $30 \mathrm{~cm}, 90 \mathrm{~cm}$, or $180 \mathrm{~cm}$ was conducted, with species (2 levels) as the main effect, followed by the Student's $t$-test [42]. To compare the distribution of roots with depth, one-way analyses of variance of belowground dry mass of $\mathrm{S}$. scoparium or $B$. dactyloides from each of the $30 \mathrm{~cm}$ segments from the $90 \mathrm{~cm}$ or $180 \mathrm{~cm}$ pots were performed with segment number (90 cm $=3$ levels; $180=6$ levels $)$ as the main effect. The distribution of roots between the two species was evaluated with one-way analyses of belowground dry mass for the $90 \mathrm{~cm}$ (3 segments) or 180 cm (6 segments) pots for each segment with species (2 levels) as the main effect. In some cases, data were either non-normal (Shapiro Wilk's Test) or the variances were not equal (Bartlett's Test). Data were logarithmically transformed which improved normality or corrected the heterschedasticity.

To estimate competition, three-way analyses of variance were performed on aboveground dry mass per plant of S. scoparium or B. dactyloides. Monoculture dry mass per pot was divided by two to obtain the mean dry mass per plant for the analyses. Main factors were species (2 levels), soil depth (3 levels), and planting combination (2 levels). All first and second order interactions were also entered into the model. To better evaluate the effects of soil depth and planting combination for each species, two-way analyses of variance were performed on aboveground dry mass per plant of $S$. scoparium or $B$. 
dactyloides with soil depth (3 levels) and plant combination (2 levels) as main effects, as well as the interaction. For each species and at each soil depth, Student's $t$-tests of aboveground dry mass between planting combination (alone or mixture) were performed. In addition, for each species and within each planting combination, one-way analyses of variance of aboveground dry mass were performed with depth as the main effect, followed by the Tukey-Kramer Multiple Comparison test.

\section{Results}

\subsection{Changes in Dry Mass across Soil Depths}

No significant differences were found in aboveground dry mass plant ${ }^{-1}$ of Schizachyrium scoparium with increasing soil depth; however, aboveground dry mass doubled in the $90 \mathrm{~cm}$ pots and remained the same at 35.5 $\pm 7.1 \mathrm{~g} \cdot$ plant $^{-1}$ dry mass in the $180 \mathrm{~cm}$ pots (Figure $1(\mathrm{a})$ ). Belowground dry mass of $S$. scoparium was significantly lower in the $30 \mathrm{~cm}$ deep pots at $4.1 \pm 0.1 \mathrm{~g} \cdot$ plant $^{-1}$ compared to the 90 and $180 \mathrm{~cm}$ deep pots, which were not significantly different from one another (Figure 1(b)). Belowground dry mass in the $180 \mathrm{~cm}$ deep pots was 17.1 $\pm 1.8 \mathrm{~g} \cdot$ plant $^{-1}$. Total dry mass for $S$. scoparium increased from $20 \mathrm{~g} \cdot$ plant $^{-1}$ to $42 \mathrm{~g} \cdot$ plant $^{-1}$ and then to 48 g. plant ${ }^{-1}$ as soil depth increased (Figure 1(c)), with dry mass being significantly different in the 90 and $180 \mathrm{~cm}$ pots compared to the $30 \mathrm{~cm}$ pots, but deeper pots were not significantly different from each other.

Aboveground dry mass of Buchloe dactyloides was significantly lower in the $30 \mathrm{~cm}$ deep pots $(8.0 \pm 0.2$ $\mathrm{g} \cdot$ pot $^{-1}$ ) than the 90 and $180 \mathrm{~cm}$ deep treatments, which were not significantly different from one another (Figure 1(a)). Aboveground dry mass increased from $8 \mathrm{~g} \cdot$ plant $^{-1}$ to 18 $\mathrm{g} \cdot$ plant $^{-1}$ and then to $25 \mathrm{~g} \cdot$ plant $^{-1}$ as soil depth increased. Belowground dry mass of $B$. dactyloides was not significantly different across the varying depths (Figure 1(b)), although dry mass was greatest at $6.0 \pm 1.0 \mathrm{~g} \cdot$ plant $^{-1}$ in the $180 \mathrm{~cm}$ deep pots. Total dry mass of $B$. dactyloides increased significantly from $12 \mathrm{~g} \cdot$ plant $^{-1}$ to $22 \mathrm{~g} \cdot$ plant $^{-1}$ to $32 \mathrm{~g} \cdot$ plant $^{-1}$ with each increase in soil depth (Figure $1(c))$.

Aboveground and total dry mass of $S$. scoparium was significantly greater than $B$. dactyloides at the $30 \mathrm{~cm}$ depth (Figures 1(a) and (c)); belowground and total dry mass of $S$. scoparium was significantly greater than $B$. dactyloides at the $90 \mathrm{~cm}$ depth (Figures 1(b) and (c)); and no differences in above-, belowground, and total dry mass were found in the $180 \mathrm{~cm}$ deep treatment (Figure 1), although S. scoparium had 29\% more total dry mass than $B$. dactyloides.

\subsection{Depth Distribution of Belowground Dry Mass}

Changes in belowground dry mass as a function of depth
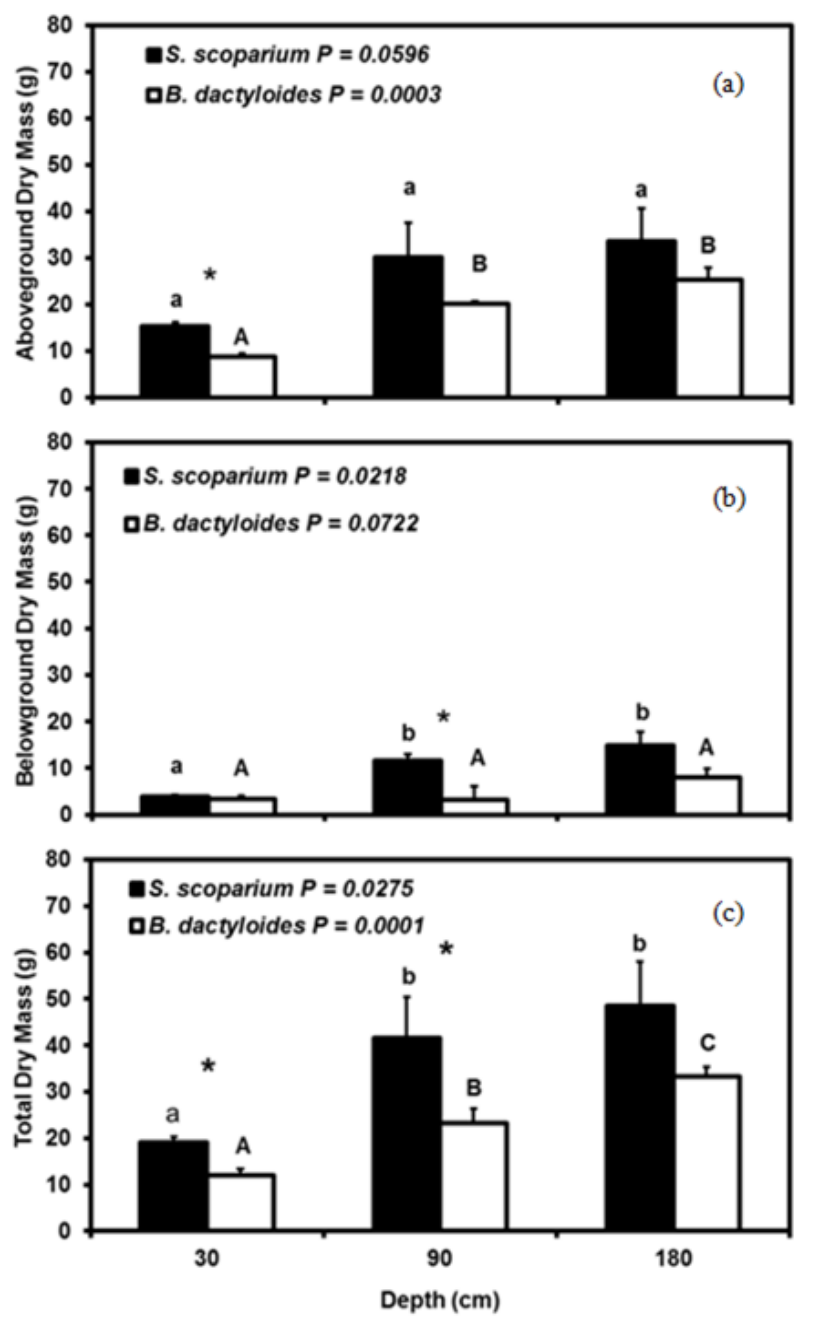

Figure 1. a) Aboveground; b) Belowground dry mass and c) Total dry mass per plant of Schizachyrium scoparium (a) and Buchloe dactyloides $(\square)$ when grown at a depth of 30 , 90 , and $180 \mathrm{~cm}$. The probability values for the effects of depth for each species are presented. Bars with the same lower case letter indicate no significant differences in dry mass per plant for $S$. scoparium and bars with the same upper case letter indicate no significant differences in dry mass per plant for $B$. dactyloides (Tukey-Kramer HSD). An asterisk indicates significant differences between $S$. scoparium and $B$. dactyloides (Student's $t$ test). Error bars represent one standard error of the mean for dry mass.

are presented in Figure 2. Regardless of the soil depth (90 or $180 \mathrm{~cm}$ ), S. scoparium belowground dry mass was significantly greater than $B$. dactyloides in each of the 30 cm segments. In the $90 \mathrm{~cm}$ depth treatment, both $S$. scoparium and $B$. dactyloides belowground dry mass were significantly greater in the top $0-30 \mathrm{~cm}$ compared to the 30 - $60 \mathrm{~cm}$ segment or 60 - $90 \mathrm{~cm}$ segment, which were not significantly different from one another (Figure 2(a)). In the $90 \mathrm{~cm}$ pots, $7.5 \mathrm{~g} \cdot$ plant $^{-1}(65 \%)$ of S. scoparium root was found in the top $30 \mathrm{~cm}$, followed by 1.6 $\mathrm{g} \cdot$ plant $^{-1}(14 \%)$ and $2.3 \mathrm{~g} \cdot$ plant $^{-1}(21 \%)$ in the next two 30 


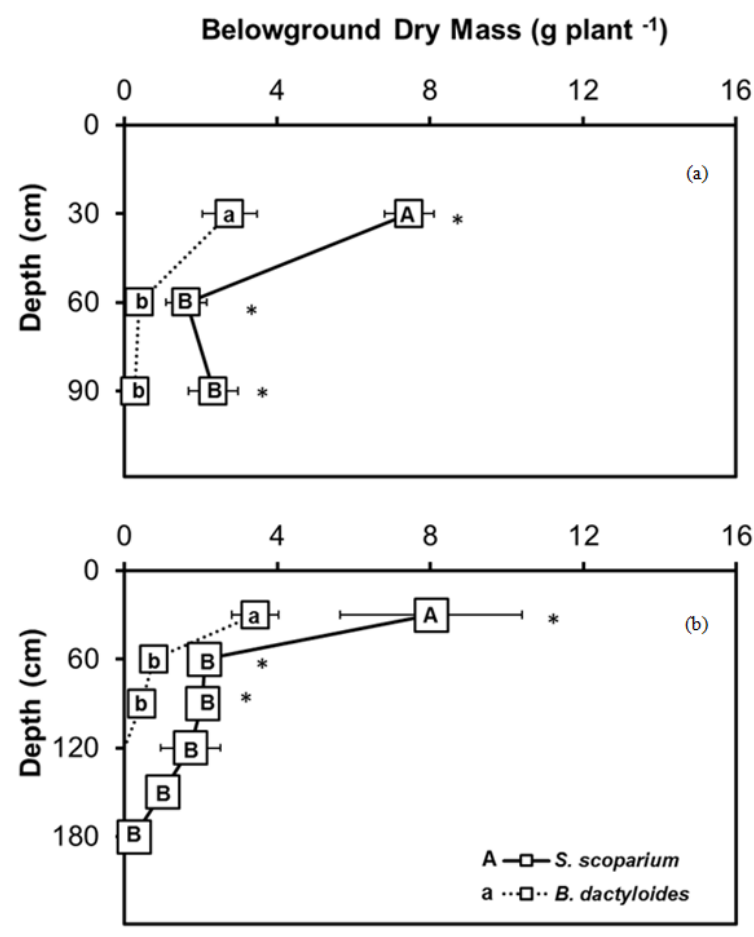

Figure 2. Belowground dry mass per plant for $30 \mathrm{~cm}$ segments for depths of A) $90 \mathrm{~cm}$ and B) $180 \mathrm{~cm}$. Means with the same upper case letter (S. scoparium) or lower case letter (B. dactyloides) are not significantly different (ANOVA; TukeyKramer HSD). For each depth and segment, S. scoparium had a significantly higher belowground dry mass than $B$. dactyloides (Student's $t$ test [*]). In the $180 \mathrm{~cm}$ depth, no $B$. dactyloides roots were found in the bottom three segments, and the data were not included in the analysis. Error bars represent one standard error of the mean. If not shown, standard errors of the mean are smaller than the symbol.

cm segments. For B. dactyloides in the $90 \mathrm{~cm}$ pots, 2.76 $\mathrm{g} \cdot$ plant $^{-1}(81 \%)$ was found in the top $30 \mathrm{~cm}$ segment, followed by $0.39 \mathrm{~g} \cdot$ plant $^{-1}(11 \%)$ and 0.28 (8\%) in the next two $30 \mathrm{~cm}$ segments.

Changes in belowground dry mass in the $180 \mathrm{~cm}$ deep pots were similar to the $90 \mathrm{~cm}$ deep pots (Figures 2(a) and (b)). Both S. scoparium and B. dactyloides belowground dry mass was significantly greater in the first $30 \mathrm{~cm}$ depth segment than all other depth segments (Figure 2(b)). For S. scoparium, belowground dry mass was not significantly different in any of the deeper $30 \mathrm{~cm}$ depth segments. In the $180 \mathrm{~cm}$ pots, $8.0 \mathrm{~g} \cdot$ plant $^{-1}$ (53\%) of S. scoparium root dry mass was found in the top $30 \mathrm{~cm}$, followed by 2.1 (14\%), 2.0 (13\%), 1.7 (11\%), 1.0 (7\%), and $0.3(2 \%) \mathrm{g}$ plant $^{-1}$ in the deeper, sequential $30 \mathrm{~cm}$ segments. For $B$. dactyloides in the $180 \mathrm{~cm}$ pots, there was $3.4 \mathrm{~g} \cdot$ plant $^{-1}(73 \%)$ in the upper $30 \mathrm{~cm}$ depth segment, followed by $0.8(17 \%)$ and $0.5 \mathrm{~g}$ plant $^{-1}(10 \%)$ in the next two $30 \mathrm{~cm}$ segments. For $B$. dactyloides, no roots were found in the bottom three soil segments. The belowground dry mass in the $30-60 \mathrm{~cm}$ segment and 60 -
$90 \mathrm{~cm}$ segment were significantly lower than the top 30 cm segment, but they were not significantly different from one another.

\subsection{Differences in Competition with Soil Depth}

Competition of the two species was significantly different across the soil depth treatments. Soil depth and planting combination (alone [monoculture] or together [mixture]) had no significant effect on aboveground dry mass of S. scoparium (Table 1). Conversely, both soil depth and planting combination had significant effects on aboveground dry mass of $B$. dactyloides (Table 1 ). No significant differences were found in aboveground dry mass of $S$. scoparium with increasing soil depth, regardless of whether grown alone or in mixture (Figure 3(a)). In addition, aboveground dry mass in mixture was the same as dry mass when grown alone in all depth treatments (although dry mass increased from approximately $17 \mathrm{~g} \cdot$ plant $^{-1}$ in the $30 \mathrm{~cm}$ pots to approximately 27 g. plant ${ }^{-1}$ in the 90 and $180 \mathrm{~cm}$ deep pots, Figure 3(a)).

For $B$. dactyloides, aboveground dry mass was significantly lower in the $30 \mathrm{~cm}$ deep pots, compared to the 90 and 180 deep ones (approximately $5 \mathrm{~g} \cdot$ plant $^{-1}$ versus about $20 \mathrm{~g} \cdot$ plant $^{-1}$ ), regardless of whether it was grown alone or in mixture with $S$. scoparium (Figure $3(\mathbf{b})$ ). Significant differences were found in the $30 \mathrm{~cm}$ deep pots with a $59 \%$ reduction in $B$. dactyloides aboveground dry mass when it was grown with $S$. scoparium (Figure 3(b)). No significant differences in B. dactyloides aboveground dry mass were found in the 90 and $180 \mathrm{~cm}$ deep pots when mixture and monoculture dry mass were compared. In all depth treatments, aboveground dry mass of $B$. dactyloides was reduced when grown with $S$. scoparium, but differences were $9 \%$ - 14\% in the deeper pots compared to about $5 \mathrm{~g} \cdot$ plant $^{-1}$ or about $59 \%$ reduction in the $30 \mathrm{~cm}$ deep pots (Figure $3(\mathrm{~b})$ ).

Relative aboveground competitive intensity was calculated for the two species at all three depths (Figure 4). Competitive intensity was greatest in the $30 \mathrm{~cm}$ depth treatments for $S$. scoparium $(-0.46)$ and for B. dactyloides $(+0.58)$ and was lower in the 90 or $180 \mathrm{~cm}$ soil depths (Figure 4). In the $90 \mathrm{~cm}$ deep pots, relative aboveground competition intensity for $S$. scoparium was very close to zero at -0.02 and for $B$. dactyloides it was +0.11 . In the $180 \mathrm{~cm}$ deep soil pots relative aboveground competition intensity was low, but higher than in the 90 cm treatments at +0.12 for $S$. scoparium and +0.22 for $B$. dactyloides.

\section{Discussion}

Changes in dry mass and competitive intensity of S. scoparium and $B$. dactyloides, two $\mathrm{C}_{4}$ grasses, were studied. This was done as a function of soil depth in the green 
Table 1. F-ratio and $P$-value for two-way analysis of variance of aboveground dry mass for Schizachyrium scoparium and Buchloe dactyloides, with depth (3 levels, 30, 90, and $180 \mathrm{~cm}$ ) and planting combination (2 levels, alone [monoculture] or mixture) as the main effects. The interaction terms was not significant and removed from the model. The error term degrees of freedom was 24.

\begin{tabular}{|c|c|c|c|c|}
\hline & Source & $\mathrm{DF}$ & $F$-ratio & $P$-value \\
\hline \multicolumn{5}{|l|}{ Species } \\
\hline & Depth & 2 & 1.61 & 0.2218 \\
\hline Schizaciryrium & Planting & & & \\
\hline \multirow[t]{2}{*}{ scoparium } & Combination & 1 & 0.05 & 0.8175 \\
\hline & Depth & 2 & 29.87 & 0.0001 \\
\hline Buchioe & Planting & & & \\
\hline dactvloides & Combination & 1 & 10.39 & 0.0036 \\
\hline
\end{tabular}
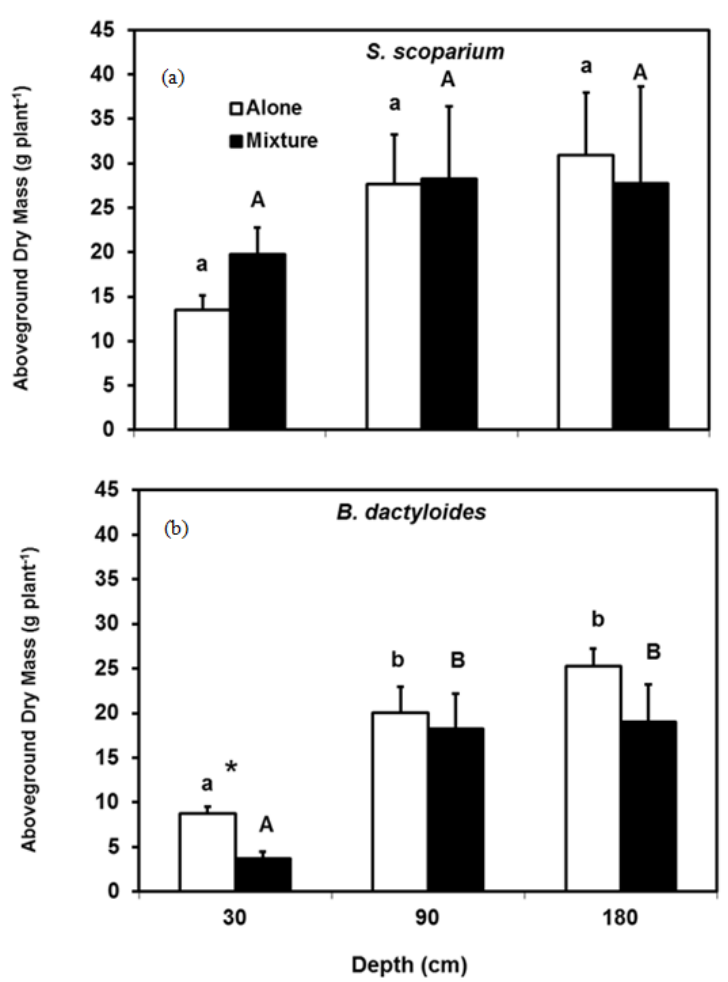

Figure 3. Aboveground dry mass per plant when grown alone $(\square)$ and in mixture ( $\square$ ) for each depth for a) Schizachyrium scoparium and b) Buchloe dactyloides. Bars with the same lower case letter indicate no significant differences in aboveground dry mass when grown alone and bars with the same upper case letter indicate no significant differences aboveground dry mass when grown in mixture (ANOVA; Tukey-Kramer HSD). An asterisk indicates significant differences between growth alone and in mixture (Student's T-test). Error bars represent one standard error of the mean.

house to better understand the association and interaction of these two species. Schizachyrium scoparium and B. dactyloides coexist in some grasslands [25,27], nevertheless $S$. scoparium seems to increase on wetter-deeper

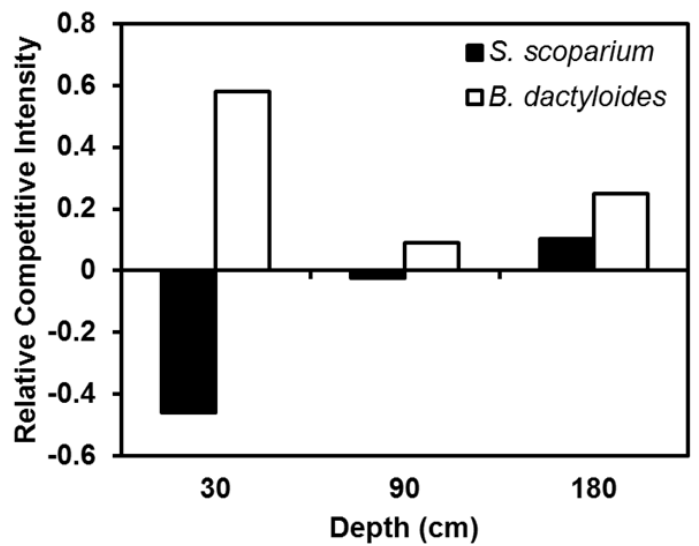

Figure 4. Relative competitive intensity $(\mathrm{RCI}=$ [Ymono Ymix]/Ymono) for Schizachyrium scoparium ( $\square$ ) and Buchloe dactyloides $(\square)$ at three soil depths $(30,90$, and $180 \mathrm{~cm})$ was calculated using aboveground dry mass. Dry mass at a proportion of 1:1 was used for Ymix.

soils and $B$. dactyloides increases on drier-shallower soils [28]. It is not clear if biotic or abiotic factors promote the habitat selectivity. Thus, soil heterogeneity including depth and nutrient level could play a role in determining the association, distribution, abundance and overlap of these two species. Many studies have documented increases in grass biomass with increased soil volume [43], soil depth [21], and gap sizes $[44,45]$. Biomass changed disproportionally with neighbor root densities, but for some species biomass increased and with other species biomass decreased [46]. Further, successional patterns and species distributions in time and space have been shown to be highly dependent upon soil depth patterns within some grasslands [47].

The root niche differentiation hypothesis [48] suggests that water reaching below the grass root zone would be accessible to deep rooted woody plants suggesting niche separation and therefore reduced competition and facilitation of co-existence of these two very dissimilar plant types. This does not seem to be the factor that allows woody plants to establish and exist with grasses in $\mathrm{C}_{4}$ grasslands and savannas which seems to be controlled by top down factors including fire and herbivory [13]. However, it seems that soil depth reduces competition and promotes co-occurrence of some grassland species including the two $\mathrm{C}_{4}$ species in the current study.

A previous study showed that root dry mass of S. scoparium was equally distributed through the soil column when growth was limited to a soil depth of $90 \mathrm{~cm}$. However, when the soil depth was increased to $180 \mathrm{~cm} 80 \%$ of the root dry mass was found in the top $30 \mathrm{~cm}$ of soil [21]. The results of root distribution of $S$. scoparium in the current experiment are similar to those reported from soil monoliths collected in the field [34]. Other factors which have been shown to influence the growth and dis- 
tribution of S. scoparium roots are soil type and past land use, with dry mass decreasing with grazing intensity but depth distribution being relatively constant [34,35]. Two other studies found approximately $80 \%$ of the root dry mass of $S$. scoparium in the top $30 \mathrm{~cm}$ in a silt loam soil monolith of $120 \mathrm{~cm}$ total depth [34,37].

It has been suggested that community structure can be determined by the level of competitive intensity [49], but this contention appears equivocal [50,51]. Competitive intensity appears lower in environments where growth is limited by abiotic factors [39]. We reported here that competitive intensity was reduced for both species when soil depth increased (Figure 4). Schizachyrium scoparium was able to reduce the growth of $B$. dactyloides in the shallow soil, but with increased soil depth and increased soil resources, competitive intensity decreased and the two species performed the same in mixture as in monoculture at the same depth. The plants in the current study were started from seed; consequently extrapolation should be limited to establishment in disturbances or gaps. In addition, we did not compare competition between seedlings and adults per se. Gaps or disturbances are important for creating mosaics in vegetation and have a wide range of spatial scales $[5,6,52,53]$.

The importance of soil resources in determining competitive outcomes between plants in arid, shortgrass prairies is unclear. In some studies, nutrient levels had no effect on competition or community composition [54]. In others, changes in community composition occurred with increases in soil nutrients [55-57]. Buchloe dactyloides was a better competitor than $B$. gracilis, regardless of the level of soil fertility [57] and B. dactyloides has also been shown to reduce the growth of seedlings of a woody plant, Prosopis glandulosa (mesquite) [58]. A previous study with $S$. scoparium and B. dactyloides in shallow pots showed that soil resources were important, with $B$. dactyloides reducing the growth of $S$. scoparium when soil nutrients were high [12].

Results of other experiments concerning the role of soil resources in determining the growth and competitive ability of $S$. scoparium are equivocal. In monoculture, increased levels of nitrogen did not affect the growth rate of S. scoparium [51]. Other studies indicated that added nitrogen increased the dry mass of S. scoparium [59]; and there is a suggestion that the response of $S$. scoparium to soil nitrogen may be water dependent [60]. In the current study, we found that increased soil depth (volume and concomitantly the amount or availability of soil resources) increased the dry mass of $S$. scoparium in monoculture from $20 \mathrm{~g} \cdot$ plant $^{-1}$ in $30 \mathrm{~cm}$ deep soil to 48 g. plant ${ }^{-1}$ in the deepest soil tested. When in competition with a southern mid-grass (Paspalum plicatulum) at various soil depths, S. scoparium was an equal competitor at a depth of $30 \mathrm{~cm}$, but $P$. plicatulum out-competed $S$. scoparium at depths of 90 and $180 \mathrm{~cm}$ [21], probably because $P$. plicatulum could access deeper soil resources.

When $S$. scoparium was examined in common garden competition experiments, it was one of the strongest competitors [51], however, in field experiments it was one of the most suppressed species [51,61]. In unfertilized plots, belowground competition limited S. scoparium; while in fertilized field plots, both above- and belowground competition limited S. scoparium [51]. Further, tilling or disturbance decreased the cover of $S$. scoparium in a mixed prairie [51]. Schizachyrium scoparium can reduce soil nitrate at shallow soil depths and in the middle of the growing season, thus deeper rooted and earlier growing species are more likely to be co-dominants [22]. Apparently S. scoparium is restricted to low productivity habitats or deeper soils [61-63].

The findings from the current greenhouse experiment between $S$. scoparium and $B$. dactyloides suggest that increased depth either 1) allows resource partitioning or 2) increases soil nutrients so that they are not limiting due to soil volume. However, based on previous experiments, we would expect $B$. dactyloides to be the better competitor when soil resources are higher [12]. This, and the root distribution pattern presented in Figure 2, lead to the conclusion that the increased depth and differential root growth patterns of these two species allows resource partitioning.

We examined the effects of soil depth on the dry mass production and distribution in the soil column and the competitive intensity between $S$. scoparium and $B$. dactyloides two $\mathrm{C}_{4}$ grasses. However, competition for light or light levels could also be a factor in determining the competitive interaction and community structure in arid and semiarid grasslands, especially for seedlings. Based on morphology, it might be expected that $S$. scoparium could shade the shorter $B$. dactyloides. Above- and belowground competition were not separated in this current experiment, and we suggest that aboveground competition could have been a factor in our experiment reducing the dry mass of $B$. dactyloides and could also be important in the field.

Ideally, field experiments would give a more realistic view of the growth and interaction of these two species, but conducting experiments in the field to evaluate soil depth is difficult at best. Our results indicated soil depth could play an important role in determining community structure in North American grasslands where these two species co-occur especially in arid or semiarid communities, particularly during the plant establishment phase. Plants segregate along a variety of niche axes, including light, soil moisture, rooting depth, partitioning of soil nutrients and combinations of these factors [24]. This segregation seems to facilitate coexistence. In a previous study with these two species [12], we reported that in 
shallow soil, partitioning of soil resources does not occur. During the establishment phase in shallow, low soil nutrient patches, B. dactyloides and S. scoparium would coexist, while in shallow, high soil nutrient patches, $B$. dactyloides would be the dominate species. From the current experiment, S. scoparium reduced the aboveground dry mass of $B$. dactyloides at the shallower depth, but in 90 or $180 \mathrm{~cm}$ deep soils, resources were no longer limiting or resource partitioning seemed to occur with a reduction of competition and therefore coexistence of the species.

\section{Acknowledgements}

We thank Ms. Kelly Jo Stephens for encouragement and help preparing and submitting this manuscript. We also thank Adriana Sotelo, Stephanie Zavala, Tristan Cofer, Sierra Dyer, Katherine Peche, Matthew Schwarz, and Catherine Zinn for reading an earlier copy of the manuscript and offering many suggestions and corrections.

\section{REFERENCES}

[1] M. J. Barbour, J. H. Burk, W. D. Pitts, F. S. Gilliam and M. W. Schwartz, “Terrestrial Plant Ecology,” Benjamin/ Cummings, Menlo Park, 1999.

[2] O. W. Van Auken, “Causes and Consequences of Woody Plant Encroachment into Western North American Grasslands," Journal of Environmental Management, Vol. 90, No. 10, 2009, pp. 2931-2942. http://dx.doi.org/10.1016/j.jenvman.2009.04.023

[3] M. Begon, C. R. Townsend and J. L. Harper, "Ecology: From Individuals to Ecosystems,” Blackwell, Malden, 2006.

[4] T. Smith and R. Smith, "Elements of Ecology," 8th Edition, Benjamin Cummings, New York, 2012.

[5] S. T. A. Pickett and P. S. White, "The Ecology of Natural Disturbance and Patch Dynamics,” Academic Press, Orlando, 1985.

[6] P. B. McEvoy, N. T. Rudd and C. S. H. Cox, "Disturbance, Competition, and Herbivory Effects on Ragwort Senecio Jacobaea Populations,” Ecological Monographs, Vol. 63, 1993, pp. 55-75.

http://dx.doi.org/10.2307/2937123

[7] E. J. Cohn, O. W. Van Auken and J. K. Bush, "Competitive Interactions between Cynodon dactylon and Acacia smallii Seedlings at Different Nutrient Levels,” American Midland Naturalist, Vol. 121, No. 2, 1989, pp. 265-272. http://dx.doi.org/10.2307/2426030

[8] J. F. Cahill Jr. and B. B. Casper, “Canopy Gaps Are Sites of Reduced Belowground Plant Competition in a Productive Old Field,” Plant Ecology, Vol. 164, No. 1, 2002, pp. 29-36. http://dx.doi.org/10.1023/A:1021228204599

[9] N. Mazia, P. M. Tognetti and E. D. Cirino, "Patch Identity and the Spatial Heterogenity of Woody Encroachment in Exotic Dominated Old-Field Grasslands," Plant Ecology, Vol. 214, No. 2, 2013, pp. 255-266. http://dx.doi.org/10.1007/s11258-013-0166-1

[10] J. K. Bush and O. W. Van Auken, "Light Requirements of Acacia smallii and Celtis laevigata in Relation to Secondary Succession on Floodplains of South Texas,” American Midland Naturalist, Vol. 115, No. 1, 1986, pp. 118122. http://dx.doi.org/10.2307/2425841

[11] O. W. Van Auken and R. J. Lohstroh, "Importance of Canopy Position for the Growth of Celtis Laevigata Seedlings,” Texas Journal of Science, Vol. 42, 1990, pp. 83-89.

[12] J. K. Bush and O. W. Van Auken, "Competition between Schizachyrium scoparium and Buchloe dactyloides: The Role of Soil Nutrients,” Journal of Arid Environments, Vol. 74, No. 1, 2010, pp. 49-53. http://dx.doi.org/10.1016/j.jaridenv.2009.07.012

[13] W. J. Bond, "What Limits Trees in $\mathrm{C}_{4}$ Grasslands and Savannas?” Annual Review of Ecology, Evolution and Systematics, Vol. 39, 2008, pp. 641-659. http://dx.doi.org/10.1146/annurev.ecolsys.39.110707.173 $\underline{411}$

[14] E. J. Chaneton, N. Mazia, W. B. Batista, A. G. Rolhauser and C. M. Ghersa, "Woody Plant Invasions in Pampa Grasslands: A Biogeographical and Community Assembly Perspective,” Elsevier, London, 2012.

[15] A. K. Knapp and T. R. Seastedt, "Detritus Accumulation Limits Productivity of Tallgrass Prairie,” BioScience, Vol. 36, 1986, pp. 662-668. http://dx.doi.org/10.2307/1310387

[16] D. S. Schimel, T. G. F. Kittel, A. K. Knapp, T. R. Seastedt, W. J. Parton and V. B. Brown, "Physiological Interactions along Resource Gradients in a Tallgrass Prairie,” Ecology, Vol. 72, No. 2, 1991, pp. 672-684. http://dx.doi.org/10.2307/2937207

[17] D. R. Lane, "Aboveground Net Primary Production across a Precipitation Gradient in the Central Grassland Region,” M.S. Thesis, Colorado State University, Colorado, 1995.

[18] E. D. Schulze, H. A. Mooney, O. E. Sala, E. Jobbagy, N. Buchmann, G. Bauer, J. Canadell, et al., "Rooting Depth, Water Availability, and Vegetation Cover along an Aridity Gradient in Patagonia,” Oecologia, Vol. 108, No. 3, 1996, pp. 503-511. http://dx.doi.org/10.1007/BF00333727

[19] R. B. Jackson, J. Canadell, J. R. Ehleringer, H. A. Mooney, O. E. Sala and E. D. Schulze, "A Global Analysis of Root Distributions for Terrestrial Biomes,” Oecologia, Vol. 108, No. 3, 1996, pp. 389-411. http://dx.doi.org/10.1007/BF00333714

[20] H. Walter, "Die Verbuschung, Eine Erscheinung der Subtropischen Savannengebiete, und Ihre Ukologischen Ursachen,” Vegetatio, Vol. 5-6, No. 1, 1954, pp. 6-10. http://dx.doi.org/10.1007/BF00299544

[21] O. W. Van Auken, J. K. Bush and D. D. Diamond, "Changes in Growth of Two $\mathrm{C}_{4}$ Grasses (Schizachyrium scoparium and Paspalum plicatulum) in Monoculture and Mixture: Influence of Soil Depth,” American Journal of Botany, Vol. 81, No. 1, 1994, pp. 15-20. http://dx.doi.org/10.2307/2445557

[22] J. Fargione and D. Tilman, "Niche Differences in Phenology and Rooting Depth Promote Coexistence with a 
Dominant $\mathrm{C}_{4}$ Bunchgrass,” Oecologia, Vol. 143, No. 4, 2005, pp. 598-606.

http://dx.doi.org/10.1007/s00442-005-0010-y

[23] J. Nippert and A. Knapp, "Linking Water Uptake with Rooting Patterns in Grassland Species," Oecologia, Vol. 153, No. 2, 2007, pp. 261-272.

http://dx.doi.org/10.1007/s00442-007-0745-8

[24] J. Silvertown, "Plant Coexistence and the Niche," Trends in Ecology \& Evolution, Vol. 19, No. 11, 2004, pp. 605611. http://dx.doi.org/10.1016/j.tree.2004.09.003

[25] J. G. Teer, J. W. Thomas and E. A. Walker, "Ecology and Management of White-Tailed Deer in the Llano Basin of Texas,” Wildlife Monographs, Vol. 15, 1965, pp. 3-62.

[26] G. L. Wolters, C. H. Sieg, A. J. Bjugstad and F. R. Gartner, "Herbicide and Fire Effects on Leafy Spurge Density and Seed Germination," United States Department of Agriculture, Rocky Mountain Forest and Range Experiment Station, Fort Collins, 1994.

[27] S. C. Fritcher, M. A. Rumble and L. D. Flake, "Grassland Bird Densities in Seral Stages of Mixed-Grass Prairie," Journal of Range Management, Vol. 57, No. 4, 2004, pp. 351-357. http://dx.doi.org/10.2307/4003858

[28] A. J. W. Woodward, S. D. Fuhlendorf, D. M. Leslie Jr. and J. Shackford, "Influence of Landscape Composition and Change on Lesser Prairie-Chicken (Tympanuchus pallidicinctus) Populations," American Midland Naturalist, Vol. 145, No. 2, 2001, pp. 261-274. http://dx.doi.org/10.1674/0003-0031(2001)145[0261:IOL CAC]2.0.CO;2

[29] J. B. Grace, "On the Measurement of Plant Competition Intensity,” Ecology, Vol. 76, No. 1, 1995, pp. 305-308. http://dx.doi.org/10.2307/1940651

[30] P. D. Steinberg, “Schizachyrium scoparium,” 2002. http://www.fs.fed.us/database/feis

[31] F. W. Albertson, "Ecology of Mixed Prairie in West Central Kansas,” Ecological Monographs, Vol. 7, No. 4, 1937, pp. 483-547. http://dx.doi.org/10.2307/1943101

[32] J. E. Weaver, "North American Prairie," University of Nebraska Press, Lincoln, 1954, p. 185.

[33] D. S. Correll and M. C. Johnston, "Manual of the Vascular Plants of Texas,” The University of Texas at Dallas, Renner, 1979, p. 1881.

[34] J. E. Weaver, "Summary and Interpretation of Underground Development in Natural Grassland Communities," Ecological Monographs, Vol. 28, No. 1, 1958, pp. 55-78. http://dx.doi.org/10.2307/1942275

[35] J. E. Weaver, "Effects of Different Intensities of Grazing on Depth and Quantity of Roots of Grasses," Journal of Range Management, Vol. 3, No. 2, 1950, pp. 100-113. http://dx.doi.org/10.2307/3893653

[36] J. L. Howard, "Buchloe Dactyloides,” 1995. http://www.fs.fed.us/database/feis

[37] H. Hopkins, "Root Development of Grasses on Revegetated Land,” Journal of Range Management, Vol. 6, No. 6, 1953, pp. 382-392. http://dx.doi.org/10.2307/3893762

[38] F. B. Taylor, R. B. Hailey and D. L. Richmond, "Soil Survey of Bexar County, Texas,” United States Depart- ment of Agriculture, Soil Conservation Survey, Washington, DC, 1966.

[39] J. L. Harper, "Population Biology of Plants," Academic Press, London, 1977, p. 892.

[40] W. Bohm, "Methods of Studying Root Systems,” In: W. D. Billings, F. Golley, O. L. Lange and J. S. Olson, Eds., Ecological Studies, Springer-Verlag, New York, 1979, pp. 247-248.

[41] A. Weigelt and P. Jolliffe, "Indices of Plant Competition," Journal of Ecology, Vol. 91, No. 5, 2003, pp. 707-720. http://dx.doi.org/10.1046/j.1365-2745.2003.00805.x

[42] J. A. Sall, A. Lehman and L. Creighton, "JMP Start Statistics: A Guide to Statistics and Data Analysis Using JMP and JMP IN Software,” Duxbury Thomson Learning, Pacific Grove, 2001.

[43] K. D. M. McConnaughay and E. I. Newman, "Is Physical Space a Soil Resource?” Ecology, Vol. 72, No. 1, 1991, pp. 94-103. http://dx.doi.org/10.2307/1938905

[44] K. D. M. McConnaughay and F. A. Bazzaz, "The Relationship between Gap Size and Performance of Several Colonizing Annuals,” Ecology, Vol. 68, No. 2, 1987, pp. 411-416. http://dx.doi.org/10.2307/1939272

[45] K. D. M. McConnaughay, "Interactions among Colonizing Annuals: Is There an Effect on Gap Size?” Ecology, Vol. 71, No. 5, 1990, pp. 1941-1951. http://dx.doi.org/10.2307/1937602

[46] K. D. M. McConnaughay and F. A. Bazzaz, "The Occupation and Fragmentation of Space: Consequences of Neighboring Roots," Functional Ecology, Vol. 6, No. 6, 1992, pp. 704-710. http://dx.doi.org/10.2307/2389967

[47] S. Fuhlendorf and F. Smeins, “The Influence of Soil Depth on Plant Species Response to Grazing within a Semi-Arid Savanna,” Plant Ecology, Vol. 138, No. 1, 1998, pp. 8996. http://dx.doi.org/10.1023/A:1009704723526

[48] H. Walter, "Ecology of Tropical and Subtropical Vegetation,” Oliver \& Boyd, Edinburgh, 1971.

[49] M. Huston, "A General Hypothesis of Species Diversity," American Naturalist, Vol. 113, No. 1, 1979, pp. 81-101. http://dx.doi.org/10.1086/283366

[50] B. D. Campbell, J. P. Grime, J. M. L. Mackey and A. Jalili, "The Quest for a Mechanistic Understanding of Resource Competition in Plant Communities: The Role of Experiments,” Functional Ecology, Vol. 5, No. 2, 1991, pp. 241-253. http://dx.doi.org/10.2307/2389262

[51] S. D. Wilson and D. Tilman, "Quadratic Variation in OldField Species Richness along Gradients of Disturbance and Nitrogen,” Ecology, Vol. 83, No. 2, 2002, pp. 492504.

http://dx.doi.org/10.1890/0012-9658(2002)083[0492:QVI OFS]2.0.CO;2

[52] K. L. Reichhardt, "Succession of Abandoned Fields in the Shortgrass Prairie, Northeastern Colorado," Southwestern Naturalist, Vol. 27, No. 3, 1982, pp. 299-304. http://dx.doi.org/10.2307/3670878

[53] D. P. Coffin and W. K. Lauenroth, "The Effects of Disturbance Size and Frequency on a Shortgrass Plant Community,” Ecology, Vol. 69, No. 5, 1988, pp. 1609-1617. http://dx.doi.org/10.2307/1941658 
[54] G. W. Rehm, W. J. Moline and E. J. Schwartz, "Response of a Seeded Mixture of Warm-Season Prairie Grasses to Fertilization,” Journal of Range Management, Vol. 25, No. 6, 1972, pp. 452-456. http://dx.doi.org/10.2307/3897006

[55] F. Rauzi, "High Rates of Nitrogen Change Composition of Shortgrass Rangeland in Southeastern Wyoming," Journal of Range Management, Vol. 31, No. 5, 1978, pp. 366370. http://dx.doi.org/10.2307/3897361

[56] F. Rauzi, "Residual Effects of Phosphorus and High Rates of Nitrogen on Shortgrass Rangeland,” Journal of Range Management, Vol. 32, No. 6, 1979, pp. 470-474. http://dx.doi.org/10.2307/3898562

[57] C. E. Richard and E. F. Redente, "Nitrogen and Phosphorus Effects on Blue Grama and Buffalograss Interactions," Journal of Range Management, Vol. 48, No. 5, 1995, pp. 417-422. http://dx.doi.org/10.2307/4002245

[58] O. W. Van Auken and J. K. Bush, "Influence of Plant Density on the Growth of Prosopis glandulosa var. glandulosa and Buchloe dactyloides," Bulletin of the Torrey Botanical Club, Vol. 114, No. 4, 1987, pp. 393-401. http://dx.doi.org/10.2307/2995994

[59] R. S. Kalmbacher, F. G. Martin and J. E. Rechcigl, "Effect of N-P-K Fertilization on Yield and Tiller Density of
Creeping Bluestem,” Journal of Range Management, Vol. 46, No. 5, 1993, pp. 452-457. http://dx.doi.org/10.2307/4002666

[60] P. O. Reardon and D. L. Huss, "Effects of Fertilization on a Little Bluestem Community," Journal of Range Management, Vol. 18, No. 5, 1965, pp. 238-241. http://dx.doi.org/10.2307/3895488

[61] O. W. Van Auken, J. K. Bush and D. D. Diamond, "Changes in Species Biomass in the Coastal Prairie of Texas When Light and Nutrients Are Altered," Canadian Journal of Botany, Vol. 70, No. 9, 1992, pp. 1777-1783. http://dx.doi.org/10.1139/b92-220

[62] O. W. Van Auken, J. K. Bush and D. D. Diamond, “The Role of Light and Nutrients in Determining Dominance of Paspalum plicatulum Michx. and Schizachyrium scoparium (Michx.) Nash, Two $\mathrm{C}_{4}$ grasses," Bulletin of the Torrey Botanical Club, Vol. 119, No. 4, 1992, pp. 401406. http://dx.doi.org/10.2307/2996728

[63] B. L. Foster, "Establishment, Competition and the Distribution of Native Grasses among Michigan Old-Fields," Journal of Ecology, Vol. 87, No. 3, 1999, pp. 476-489. http://dx.doi.org/10.1046/j.1365-2745.1999.00366.x 